\title{
EARLY TREATMENT OF NONSYNDROMIC OLIGODONTIA: A CLINICAL CASE REPORT
}

\author{
TRATAMENTO PRECOCE DA OLIGODONTIA NÃO-SINDRÔMICA: RELATO \\ DE CASO CLÍNICO
}

\author{
Carolina Ribeiro STARLING ${ }^{1}$; Caroline Mathias Carvalho de SOUZA²; \\ Rogério Frederico Alves FERREIRA ${ }^{3}$; Marcos Alan Vieira BITTENCOURT ${ }^{3}$ \\ 1. PhD student, Department of Pediatric Dentistry and Orthodontics, Federal University of Rio de Janeiro, Rio de Janeiro, RJ, Brazil; 2. \\ PhD student, Department of Restorative Dentistry, Piracicaba Dental School, State University of Campinas, Piracicaba, SP, Brazil; 3. \\ Associate Professor of Orthodontics, Federal University of Bahia, Salvador, BA, Brazil. alan_orto@yahoo.com.br
}

\begin{abstract}
This report aims to describe the clinical case of a 10-year-old male patient (R.C.B.C.), presenting nonsyndromic oligodontia with maternal family trait and absence of 22 permanent teeth. Clinically, the patient had prolonged retention of some primary teeth and presence of permanent maxillary left central incisor, permanent mandibular right central incisor and four first permanent molars. Radiographically, only permanent maxillary second molars and mandibular third molars were developing, whereas all other germs of permanent teeth were missing. Treatment consisted of maxillary expansion followed by moving permanent maxillary left central incisor bucco-mesially, and rehabilitation of spaces with removable denture, where the main goal was to restore function and esthetic harmony. The case has been monitored for the past six years. Nonsyndromic oligodontia is a rare condition that poses significant functional and psychosocial difficulties. Treatment usually requires a multidisciplinary approach among which pediatric dentistry and orthodontics play a major role. In view of its complexity, treatment should be initiated as early as possible to minimize future functional and aesthetic issues. Dental implants are considered as definitive treatment of cases of oligodontia, however, until the patient reached the ideal age, other treatments to ensure aesthetics and function must be performed.
\end{abstract}

KEYWORDS: Diagnosis. Tooth Agenesis. Pediatric Dentistry. Orthodontics.

\section{INTRODUCTION}

Tooth agenesis is a very common developmental anomaly (LIANG et al., 2016; HIREMATH, 2012; DE COSTER et al., 2009; RÓZSA et al., 2009; PUNITHAVATHY, PRIYA, INDHUMATHI, 2012) whereby primary and/or permanent tooth formation is impaired due to compromised odontogenesis (HIREMATH, 2012). As a result, there is a reduction in the number of teeth in the oral cavity. Clinically, this anomaly can affect various combinations of teeth, and may be associated with other dental development anomalies. It can occur as a sporadic case or as a family trait, whether in isolation (nonsyndromic), or associated with cleft lip and palate, or with syndromes (HIREMATH, 2012; DE COSTER et al., 2009; PUNITHAVATHY, PRIYA, INDHUMATHI, 2012; ZHANG, PENG, FENG, 2015). Tooth agenesis can be classified, according to the number of missing teeth, as hypodontia, the congenital absence of one to six teeth, excluding third molars; oligodontia, more than six teeth, and anodontia, all teeth (HIREMATH, 2012; PUNITHAVATHY, PRIYA, INDHUMATHI, 2012; LIU et al., 2015; GURUPRASAD et al., 2011).

Although diagnosis is performed clinically, it should be confirmed by radiographic examination
(PUNITHAVATHY, PRIYA, INDHUMATHI, 2012). Clinical diagnosis can be performed by inspecting primary dentition from the age of three, and permanent teeth from ages twelve to fourteen. Radiographically, the diagnosis can be made earlier, from the age of six, being panoramic radiography the best investigation tool (HIREMATH, 2012; GURUPRASAD et al., 2011). Tooth agenesis poses daunting functional and psychosocial challenges (ZHANG, PENG, FENG, 2015). Early diagnosis and treatment options are often limited (HIREMATH, 2012; DE COSTER et al., 2009). However, dental treatment is important since oral health is essential for proper nutrition and speech as well as for facial aesthetics and emotional development of the individual (HIREMATH, 2012; ZHANG, PENG, FENG, 2015; GURUPRASAD et al., 2011). Treatment can vary from conservative management using removable dentures to oral rehabilitation with implant-supported dentures after preliminary orthodontic treatment and, when necessary, surgical procedures (ZHANG, PENG, FENG, 2015). Therefore, cases should be planned based on an interdisciplinary approach, as this anomaly directly affects occlusion due to improper position of adjacent teeth, supraocclusion of antagonist teeth, alveolar process growth deficiency associated with missing teeth, periodontal problems, 
undesirable aesthetics and phonetic problems (HIREMATH, 2012; PANNU et al., 2014).

The purpose of this article is to report an unusual case, i.e., that of R.C.B.C., a 10-year-old male patient suffering from nonsyndromic oligodontia (NO) with 22 permanent teeth missing. Hopefully it will assist pediatric dentists and orthodontists in planning the treatment of this anomaly.

\section{CASE REPORT}

R.C.B.C., a male, 10-year-old patient, presented at the outpatient clinic of the Department of Orthodontics, School of Dentistry, Federal University of Bahia, with the following complaint: "My teeth are crooked, I want them to be normal; and one tooth is missing, too."

His medical history revealed no relevant events, whereas his family history showed that his mother had agenesis of the maxillary premolars and second mandibular premolars. A functional analysis disclosed atypical speech and swallowing, and thumb sucking habit. Extraoral clinical examination revealed no irregularities in his skin, hair or nails,
STARLING, C. R. et al.

which might be compatible with other syndromes. He had a mesocephalic, symmetrical facial pattern with a slightly convex profile (Figure 1).

Intraoral clinical examination revealed that patient had satisfactory oral hygiene with no caries activity. The patient had mild atresia of the maxillary dental arch, anterior dental crossbite and anterior open bite. Prolonged retention was detected in some incisors, all primary canine and molar teeth. All permanent first molars, the maxillary left central incisor (MLCI) and mandibular right central incisor had erupted. The maxillary right central incisor and maxillary left lateral incisor (MLLI) were missing, and the MLCI was tipped distally. His first permanent molars displayed normal occlusion on the left side, and a class II relationship was detected on the right side. All teeth exhibited normal size, shape and color (Figure 2).

Panoramic radiography revealed agenesis of 22 permanent teeth, with the development of only permanent maxillary second molars and mandibular third molars (Figure 3). Based on these findings, the patient was diagnosed as having $\mathrm{NO}$ with maternal family trait.
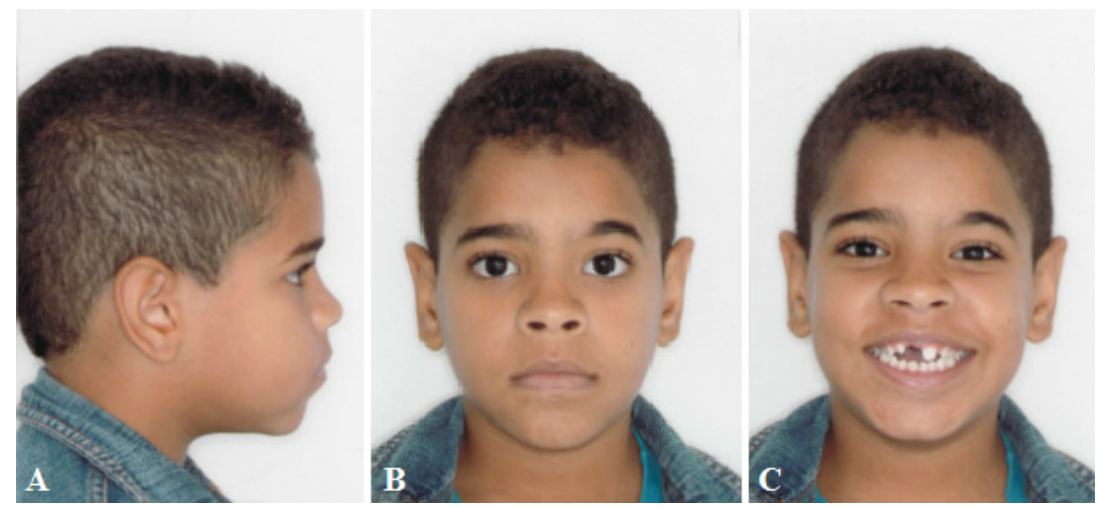

Figure 1. Initial extraoral photographs: A - Profile, B - Frontal, C - Smiling.

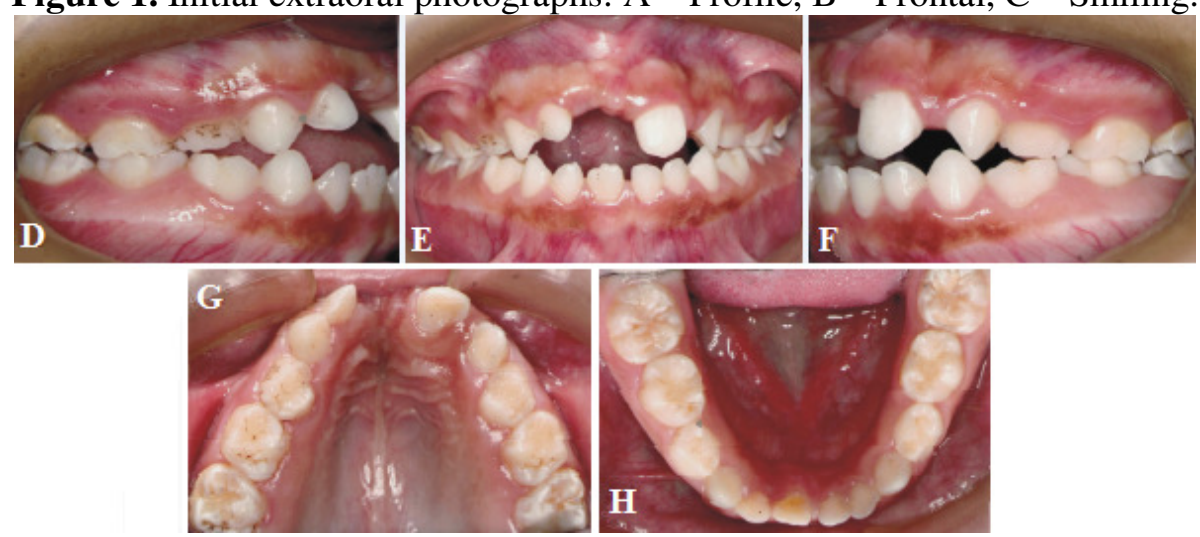

Figure 2. Initial intraoral photographs: D - Right side, E - Frontal, F - Left side, G - Upper occlusal, H Lower occlusal. 


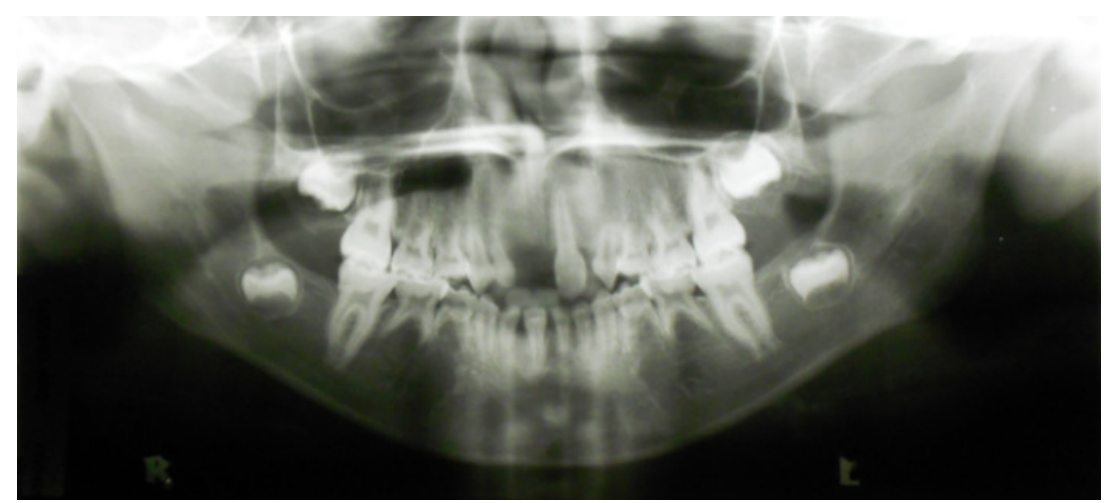

Figure 3. Initial panoramic radiograph.

Treatment consisted in placing a Porter arch (Figure 4) - activated for six months - to correct the atresia in the maxillary arch; placing a removable appliance with a coil spring - activated for seven months - to move the MLCI mesially, correct the midline and create space for replacement of the
MLLI, which was missing (Figure 5); and other removable appliance with a finger spring - activated for two months - to correct the anterior crossbite of the MLCI (Figure 6). This latter appliance had two stock teeth to replace the maxillary right central incisor and MLLI, restoring aesthetics and function.

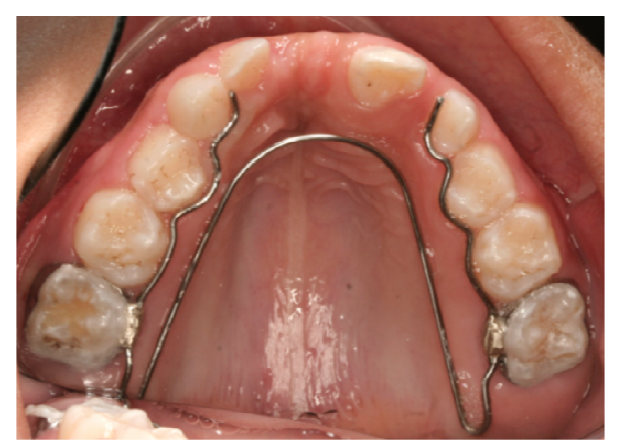

Figure 4. Porter arch to expand the upper dental arch
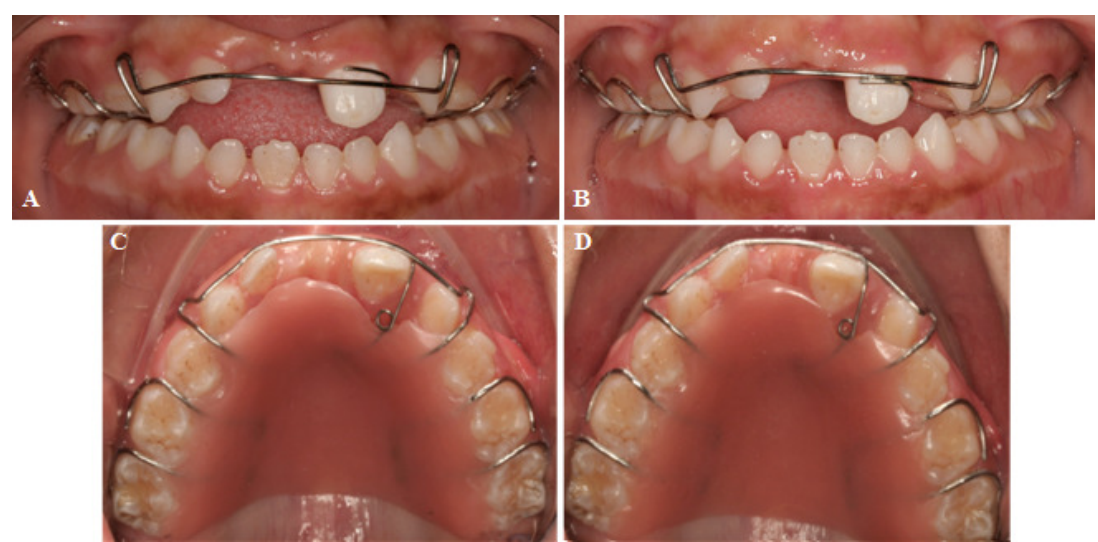

Figure 5. Plate with coil spring to move tooth 21 mesially: A and B - Frontal photographs before and after spring action, $\mathrm{C}$ and $\mathrm{D}$ - Upper occlusal photographs before and after spring action. 


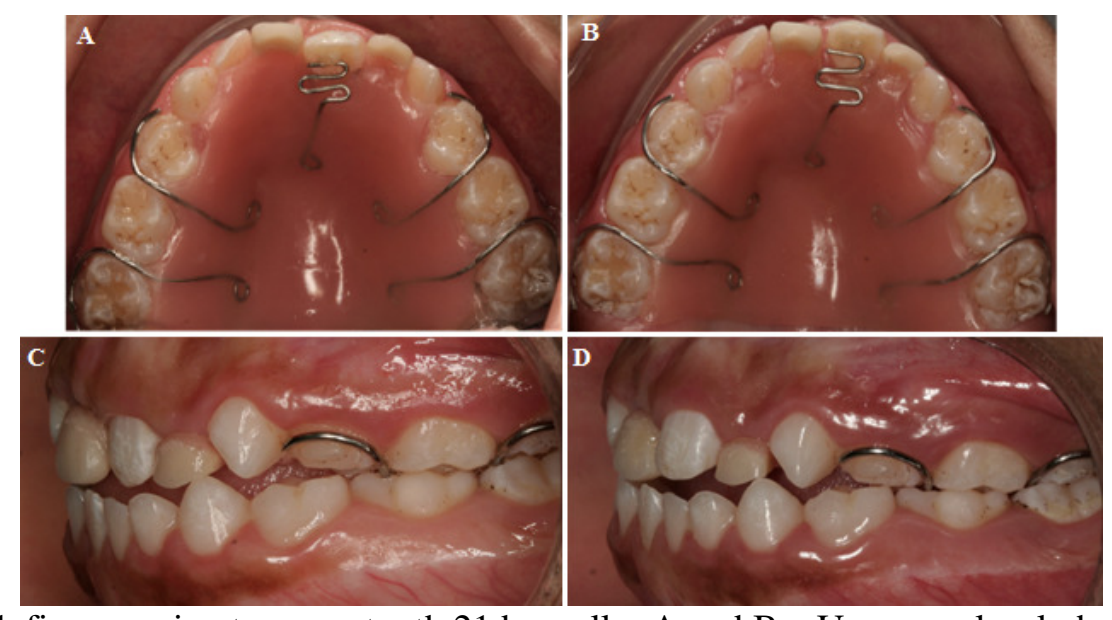

Figure 6. Plate with finger spring to move tooth 21 buccally: A and B - Upper occlusal photographs before and after spring action, $\mathrm{C}$ and $\mathrm{D}$ - Left side photographs before and after spring action.

Thereafter, another appliance with only stock teeth was placed, functioning as a removable partial denture and maintaining the orthodontic movements performed so far (Figure 7). Aiming to correct functional problems and anterior open bite, the patient was referred to a speech therapist.
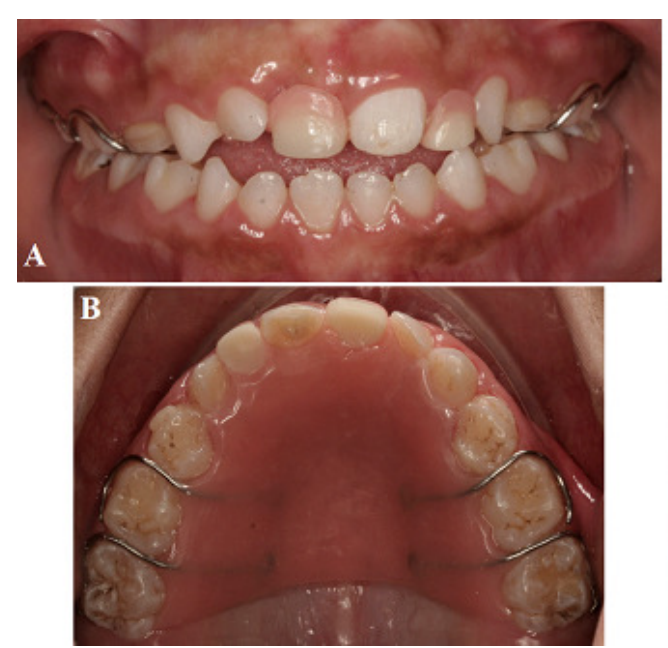

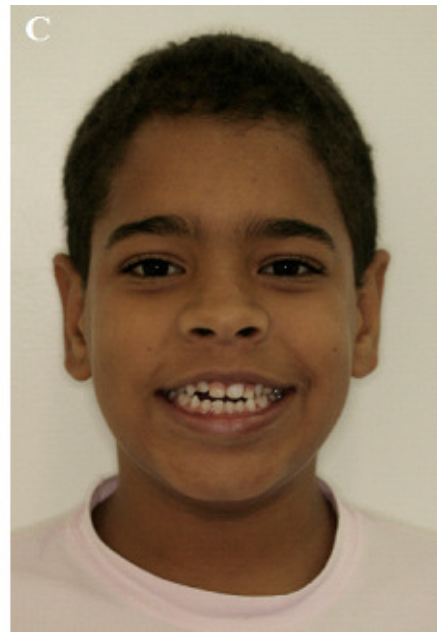

Figure 7. Plate with stock teeth, post-orthodontic treatment, functioning as removable partial dentures: A Frontal intraoral photograph, B - Upper occlusal photograph, C - Frontal extraoral photograph, smiling.

The primary teeth were kept and the patient has been monitored for the last six years. The removable appliance with stock teeth should be often replaced in order not to hinder the physiological alveolar vertical growth of the maxilla and replace primary teeth exfoliated over time. During follow-up, the patient was re-evaluated every six months. At each visit, we have made the necessary adjustments on the device and it was replaced twice. Following the end of bone growth, the patient will be referred for a removable partial or an implant-supported denture in order to achieve a functional occlusion with appropriate guides both laterality as protrusive.

In this case, the patient was under early treatment with pediatric dentist, orthodontist and speech therapist. There was no need to follow up with psychologist because the patient had good collaboration to dental treatment, neither prosthetist yet, since he had only one tooth missing, which was placed back in his own orthodontic device.

\section{DISCUSSION}

Permanent teeth exhibit a higher prevalence of tooth agenesis than primary teeth (GURUPRASAD et al., 2011). Hypodontia is the most common form of agenesis, corresponding to $58.7 \%$ to $88 \%$ of cases. Only about $0.1-0.3 \%$ of population have oligodontia (PUNITHAVATHY, PRIYA, INDHUMATHI, 2012; THIMMEGOWDA et al., 2015). 
Oligodontia is a more serious form of expression, considered rare (LIANG et al., 2016; GURUPRASAD et al., 2011). It is often associated with syndromes and/or severe systemic abnormalities, and individuals with syndromic oligodontia have, on average, more missing teeth than patients with NO (HIREMATH, 2012). In this case report, the patient was diagnosed with NO, with absence of 22 permanent teeth, being considered a rare case.

Although it may on occasion be caused by environmental factors, in most cases tooth agenesis has a genetic etiology. Among the genetic causes are changes in the expression of specific genes involved in odontogenesis. Some environmental factors include infections, such as rubella and measles during pregnancy; trauma to the alveolar processes; use of chemicals or drugs such as thalidomide and dioxin; chemotherapy; radiotherapy; and disturbances in the innervations of the jaw. Other etiologies have been described, such as nutritional factors, endocrine disorders and association with syndromes (HIREMATH, 2012; DE COSTER et al., 2009).

It is widely accepted that failures in odontogenesis that result in agenesis are caused by variations in the sequence of genes expressed during tooth development (JIMÉNEZ-CASTELLANOS et al., 2005). So far, three genes have been primarily associated with nonsyndromic agenesis, especially in cases of severe oligodontia: MSX1, AXIN2 and PAX9 (LIANG et al., 2016; HIREMATH, 2012; DE COSTER et al., 2009; LIU et al., 2015; GURUPRASAD et al., 2011). In this case, it was not possible to identify the etiologic factor of the NO. The most likely hypothesis is heredity, since his mother had agenesis of the maxillary premolars and second mandibular premolars. However, genetic evaluations were not performed.

Severe cases have been attributed do female gender in some reports, with a ratio of $3: 2$ (HIREMATH, 2012; DE COSTER et al., 2009; GURUPRASAD et al., 2011). In this case, the patient's gender does not match the most severe cases found in the literature.

According to Punithavathy et al. (2012), bilateral agenesis is more common than unilateral and the proportion of missing teeth in the maxilla is predominantly larger than in the mandible. In this case, there was no preference between sides and dental arches, however, there was a prevalence of bilaterality- with the exception of the incisors.

Regarding location, all case reports reviewed in the literature showed absence of all third molars (HIREMATH, 2012; RÓZSA et al., 2009; PUNITHAVATHY, PRIYA, INDHUMATHI, 2012; JIMÉNEZCASTELLANOS et al., 2005). In this case, two developing third molars were present among the ten permanent teeth, contradicting all authors reviewed.

Guruprasad et al. (2011) and Rózsa et al. (2009) argue that agenesis of the maxillary central incisors, canines or permanent first molars appears to be quite exceptional. Furthermore, according to Jiménez-Castellanos et al. (2005), canines are the least affected teeth as their absence is considered rare. It is possible to conclude that the case reported in this article is unusual as it presents with agenesis of a maxillary central incisor and all permanent canines.

The choice of treatment depends on the analysis of various criteria such as occlusion, patient's age, position, color and morphology of the remaining teeth, and patient desire (MALLAYYA, 2012). The preservation of retained primary teeth is essential for treatment planning, particularly the canines. Retained primary teeth with minimal root resorption preserves the integrity of the dental arch, providing good potential for future prosthetic rehabilitation (RÓZSA et al., 2009; JIMÉNEZCASTELLANOS et al., 2005), as was done in this case, combining orthodontic and prosthodontics approach, due to the patient's age and condition, and an early diagnosis.

Patients presenting with oligodontia must be evaluated carefully for associated syndromes since nonsyndromic cases are rare, with few reports in the literature. Treatment usually requires a multidisciplinary approach, including pediatric dentistry, orthodontist, prosthodontist, implantodontist, speech therapist and psychologist, and in view of the complexity involved treatment should be initiated as early as possible to minimize future functional and aesthetic issues. Dental implants are considered as definitive treatment of cases of oligodontia, however, until the patient reached the ideal age to install them, other treatments to ensure aesthetics and function must be performed (ZHANG, PENG, FENG, 2015).

RESUMO: O objetivo deste trabalho é descrever o caso clínico do paciente R.C.B.C., dez anos de idade, gênero masculino, portador de oligodontia não associada à síndrome, com traço familiar materno e ausência de 22 dentes permanentes. Clinicamente, o paciente apresentava retenção prolongada de alguns incisivos, todos os caninos e molares decíduos e presença do incisivo central superior esquerdo, incisivo central inferior direito e os quatro primeiros molares, 
todos da dentição permanentes. Radiograficamente, apenas os segundos molares superiores e os terceiros molares inferiores estavam em desenvolvimento, com ausência dos demais germes dos dentes permanentes. Terapeuticamente, foi instituída a expansão maxilar seguida de mesialização e vestibularização do incisivo central superior esquerdo e de reabilitação com prótese removível, sendo o objetivo principal restaurar a harmonia estética e a função. O caso foi acompanhado há seis anos. A oligodontia não-sindrômica é considerada rara e impõe importantes dificuldades funcionais e psicossociais aos seus portadores. Geralmente, o tratamento requer uma abordagem interdisciplinar, onde a odontopediatria e a ortodontia desempenham papel primordial. Devido à complexidade envolvida, o tratamento deve ser iniciado o mais cedo possível, para minimizar futuras questões funcionais e estéticas. Os implantes dentários são considerados como tratamento definitivo para os casos de oligodontia, entretanto, até os pacientes alcançarem a idade ideal, outros tratamentos para garantir estética e função devem ser realizados.

PALAVRAS-CHAVE: Diagnóstico. Agenesia Dentária. Odontologia Pediátrica. Ortodontia.

\section{REFERENCES}

DE COSTER, P. J.; MARKS, L. A.; MARTENS, L. C.; HUYSSEUNE, A. Dental agenesis: genetic and clinical perspectives. J Oral Pathol Med., v. 38, n. 1, p. 1-17, Jan 2009. https://doi.org/10.1111/j.16000714.2008.00699.x

GURUPRASAD, R.; NAIR, P. P.; HEGDE, K.; SINGH, M. Non syndromic oligodontia. J Indian Dent Assoc., v. 3, p. 450-453, Apr 2011.

HIREMATH, M. C. Nonsyndromic oligodontia: A rare case report. Archives of Oral Sciences and Research., v. 2, n. 2, p. 103-107, 2012.

JIMÉNEZ-CASTELLANOS, E.; CARMONA, A.; CATALINA-HERRERA, C. J.; CORDERO, E.; JIMÉNEZCASTELLANOS, J. Variations in the number of human permanent teeth: hypodontia. Eur J Anat., v. 9, n. 1, p. 23-27, Feb 2005.

LIANG, J.; QIN, C.; YUE, H.; HE, H.; BIAN, Z. A novel initiation codon mutation of PAX9 in a family with oligodontia. Arch Oral Biol., v. 61, p. 144-148, Jan 2016. https://doi.org/10.1016/j.archoralbio.2015.10.022

LIU, H.; DING, T.; ZHAN, Y.; FENG, H. A. Novel AXIN2 Missense Mutation Is Associated with NonSyndromic Oligodontia. PLoS One., v. 10, n. 9, p. e0138221, Sep 2015.

https://doi.org/10.1371/journal.pone.0138221

PANNU, P.; GALHOTRA, V.; AHLUWALAI, P.; GAMBHIR, R. S. Non-syndromic oligodontia in permanent dentition: a case report. Ghana Med J., v. 48, n. 3, p. 173-176, Sep 2014. https://doi.org/10.4314/gmj.v48i3.10

PUNITHAVATHY, J. B. J.; PRIYA, G.; INDHUMATHI, E. S. Familial nonsyndromic oligodontia. Contemp Clin Dent., v. 3, n. Suppl 2, p. 188-190, Sep 2012.

RÓZSA, N.; NAGY, K.; VAJÓ, Z.; GÁBRIS, K.; SOÓS, A.; ALBERTH, M.; et al. Prevalence and distribution of permanent canine agenesis in dental paediatric and orthodontic patients in Hungary. Eur J Orthod., v. 31, n. 4, p. 374-379, Aug 2009. https://doi.org/10.1093/ejo/cjp018

THIMMEGOWDA, U.; PRASANNA, P.; ATHIMUTHU, A.; BHAT, P.K.; PUTTASHAMACHARI, Y. A Nonsyndromic Autosomal Dominant Oligodontia with A Novel Mutation of PAX9-A Clinical and Genetic Report. J Clin Diagn Res., v. 9, n. 6, p. 8-10, Jun 2015.

ZHANG, X. X.; PENG, D.; FENG, H. L. Prosthodontic Treatment for Severe Oligodontia with Long-term Follow-up. Chin J Dent Res., v. 18, n. 3, p. 163-169, Sep 2015. 